\title{
Phenological Development and Water Rela- tions in Plains Silver Sagebrush
}

\author{
RICHARD S. WHITE AND PAT O. CURRIE
}

\begin{abstract}
Detailed measurements were made on silver sagebrush plants to quantify phenological development, plant water potential, and soil water status. Measurements were made at bi-weekly intervals from early April to late October. A phenological scoring system was employed and the data used in linear regression equations with calendar date or plant water potential as independent variables. Both variables were used successfully in predicting phenological development in silver sagebrush. However, calendar date had less variability around the regression line, and it would therefore probably have greater direct application. The results should prove of value in future autecological studies of the species and will provide important information to manage plant communities that contain silver sagebrush.
\end{abstract}

Species of sagebrush (Artemisia spp.) have long been recognized as having an important ecological role on rangelands over much of the West. In areas where it is abundant, sagebrush often has considerable economic impact on livestock operations, and it is frequently regarded as a plant which should be reduced or eliminated through brush control practices. In other circumstances, sagebrush species may provide desirable forage or cover for either livestock or wildlife. The degree of desirability of sagebrush generally depends upon the species and in some cases the variety that is present. The complexity of this relationship is exemplified from the vast literature that has been compiled. Harniss et al. (1981), for example, cite almost 1,500 references dealing primarily with the section Tridentatae of Artemisia.

The majority of published material on sagebrush species has been directed toward a better understanding of big sagebrush (Artemisia tridentata). Since big sagebrush occupies more acreage than other Artemisia species, this is not surprising. In comparison, very little research work has dealt directly with silver sagebrush (Artemisia cana). However, silver sagebrush has been estimated to occupy 13 million ha in the 11 western states, and it ranks second in importance to big sagebrush (Beetle 1960). Therefore, it merits much more intensive research attention. Additional information is particularly needed with respect to how to manage plant communities in which silver sagebrush is a major component.

Knowledge of phenological development in plants is basic to an understanding of how they react to different management practices. Hyder et al. (1962), for example, found substantial differences in herbicide efficacy on big sagebrush and green rabbitbrush (Chrysothamnus viscidiflorus) in relation to environmental, phenological, and physiological conditions. With silver sagebrush, White and Currie (1983) reported wide differences in response to fire that could have been caused by differences in phenological development of the plant. Lack of more precise information on shrub phenology, however, has too often limited interpretation of research results. Because a more concise description of phenological events would be of considerable benefit to understanding man-

Authors are research plant physiologist and range scientist, respectively, USDA, ARS, Ft. Keogh Livestock and Range Research Station, Route 1, Box 2021, Miles City, Mont. 59301

This study is a contribution from USDA Agriculture Research Service, Livestock and Range Research Station, and the Montana Agricultural Experiment Station, Miles City. Journal Series No. J-1454

Manuscript accepted March 12, 1984.
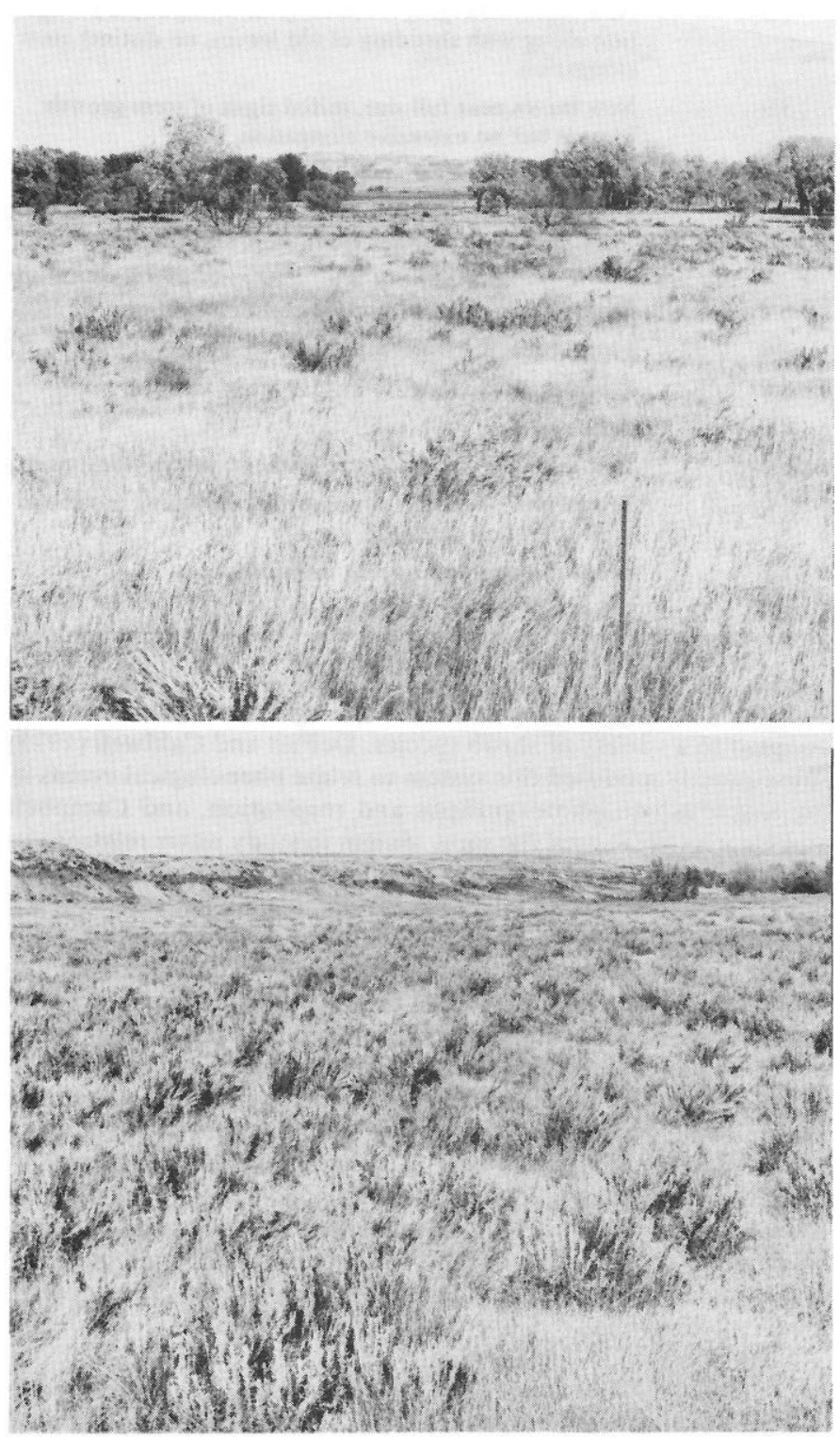

Fig. 1. General view of two of the three silver sagebrush study areas. The lightly invested area is illustrated in la and the heavily infested area is shown in $1 b$.

agement options, we decided to establish a more comprehensive description of phenology in Plains silver sagebrush (Artemisia cana cana). We also believed that it was important to define more concisely water relationships that existed during the period when the plant was physiologically most active.

Shrub phenology has received relatively little attention in comparison to phenological development in grass species. West and 
mixed prairie in the Northern Great Plains (Daubenmire 1978,

Table 1. Numeric scores that were assigned to phenological stages of development in silver sagebrush. Principle anatomical characteristics are indicated in the morphological description.

\begin{tabular}{cl}
\hline \hline $\begin{array}{l}\text { Numeric } \\
\text { Phenological } \\
\text { Score }\end{array}$ & Morphological Description \\
\hline 0.0 & Winter dormant, foliage dull gray. \\
1.0 & Buds swelling, initial signs of leaf extension present but \\
& no obvious elongation, foliage green. \\
& New leaves emerging from buds, showing rapid elonga- \\
2.0 & tion along with shedding of old leaves, no distinct stem \\
& elongation. \\
3.0 & New leaves near full size, initial signs of stem growth \\
& present but no extensive elongation. \\
4.0 & Undergoing rapid stem elongation of primary stems. \\
5.0 & Secondary stem growth evident in axes of leaves of pri- \\
& mary stcms but without much stem elongation in \\
6.0 & secondary tissue. \\
7.0 & Secondary stems undergoing rapid elongation. \\
8.0 & Floral branches differentiating. \\
9.0 & Floral buds swelling. \\
10.0 & Anthesis. \\
11.0 & Post anthesis, pre-seed development, yellow floral parts. \\
12.0 & Brown and dry floral parts, seeds developing moist and \\
13.0 & semi-succulent achenes. \\
\hline & Seeds dry and undergoing dissemination. \\
& Leaves on floral branches shed. \\
\hline
\end{tabular}

Wein (1971) suggested a numeric scoring system that could be adapted to a variety of shrub species. DePuit and Caldwell (1973) subsequently modified this system to relate phenological events in big sagebrush to photosynthesis and respiration, and Campbell and Harris (1977) used the same system to study water relations in big sagebrush. An acceptable numeric scoring system, however, has not been devised for silver sagebrush. Moreover, the sequence of phenological events has not even been described although it seems likely that phenological development could account for some of the response differences that have been observed under different management regimes. Our work has been designed to obtain an increased understanding of phenological development in silver sagebrush. Specific objectives were: (1) to define readily recognizable phenological stages of development in silver sagebrush that would be of value in subsequent autecological and management related studies, (2) to relate phenological response to calendar date with respect to ontogenetic development within a single season, and (3) to examine the extent to which soil moisture and plant moisture stress ${ }^{1}$ were related to phenological development.

\section{Methods}

Data for this work were obtained in 1981 from 3 study areas on the Livestock and Range Research Station west of Miles City, Mont. Individual study areas were 0.56 ha in size and measured 61.0 by $91.5 \mathrm{~m}$. Vegetation of the study areas was typical of the

1 As pointed out by Taylor (1968), considerable discrepancy exists when using terminology dealing with plant water relations. We have chosen to regard "plant moisture stress" and "plant water potential" as homologous and have used them interchangeably. Both terms have been used extensively by researchers so that there seems to be little differentiation between the two.
Weaver and Clements 1938). Major plant species included western wheatgrass (Agropyron smithii), green needlegrass (Stipa viridula), annual bromes (Bromus spp.), threadleaf sedge (Carex filifolia), and Plains silver sagebrush. Long-term precipitation for the area averages about $350 \mathrm{~mm} /$ year, but it commonly ranges from 250 to $450 \mathrm{~mm} /$ year. During the year this study was conducted, precipitation was $272 \mathrm{~mm}$. Temperatures during the study were near normal throughout the growing season, and hence they probably exerted a normal influence on phenological development.

Soils on the study sites were Borollic Camborthids and belonged to the Yamac and Kobar series. These series are characterized as deep, well-drained soils that form from alluvial sediments. The primary difference between series is in texture. The Kobar series is a silty clay loam, while the Yamac series is a loam. Both series are relatively fertile and represent highly productive range sites. Topography was nearly level and study sites were typical of plant communities in which silver sagebrush often becomes abundant.

Selection of individual study areas was based primarily on stature and density of silver sagebrush. An effort was made to select areas that were representative of plant communities throughout the Northern Great Plains where silver sagebrush can become abundant. Three degrees of sagebrush infestation (light, moderate, heavy) were represented by the different study areas. The lightly infested area was characterized by sagebrush plants that were generally under $1 \mathrm{~m}$ in height. Plants were scattered in a relatively open stand with distances between individuals commonly 5 to 10 $\mathrm{m}$. The heavily infested area had sagebrush plants that commonly exceeded $1 \mathrm{~m}$ in height, and intervals between individuals were usually less than $2 \mathrm{~m}$. The moderately infested area was intermediate. Figure 1 shows the range of infestation that was encountered across the 3 study areas.

Five $100 \mathrm{~m}$ long transect lines were established in each of the 3 study areas. Three plants were selected at random for detailed analysis from each transect at bi-weekly intervals between the first of April and the end of October. This interval covered that period of the year when plants showed first morphological signs of physiological activity and continued until seeds were dispersed and plants were becoming dormant. The 45 plants that were sampled on each date were evaluated for phenological development and assigned a numeric score based on morphological categories and the approach suggested by West and Wein (1971) (Table 1).

Moisture conditions were evaluated by means of a neutron scattering depth gauge for measuring soil moisture and a Scholander pressure bomb for determining plant moisture stress (Waring and Cleary 1967). Soil water content was derived from a total of 12 neutron access tubes located within the 3 study areas. Readings were taken every 2 weeks at the same time phenological observations were made. Sample depths measured were 30,91, 122, and $152 \mathrm{~cm}$. Plant water potential was determined on each date for each of the 45 plants that were phenologically scored. Readings were obtained between 8 and 11 AM. This interval was selected because diurnal variation with individual plants at this time showed little deviation from values obtained at sunrise. Three twigs were sampled from each plant. Pressure bomb values were then obtained for each twig, and the plant moisture stress of each plant was calculated as the average of 3 readings.

Results were analyzed statistically by regarding individual plants within each study area as replications. Mean value comparisons between areas wcre made within each sampling date by using Student's $t$-test. Regression relationships were derived by pooling observations of plants from all 3 areas. Dates and plant moisture stresses were used as independent variables in separate linear equations to predict phenological stage of development.

\section{Results and Discussion}

Bud swelling in early April was the first readily observable sign of the end to winter dormancy in silver sagebrush plants. This was 
followed by leaf expansion, twig growth, floral differentiation, and seed dispersal with a normal progression of phenological events. Comparison of our results with general observations reported by Harvey (1981) over a 3-year period indicated that phenological development during our study was characteristic of normal morphogenesis in the species. It is likely, therefore, that our results are typical of those usually encountered. However, it should be noted that year-to-year weather differences in the same area can result in different phenological patterns with respect to date or morphological development.

Comparison of phenological development among the 3 study areas showed small differences throughout the duration of the study with respect to phenological scoring units (PSU). Differences between high and low PSU values on individual sampling dates were less than 0.2 on 10 occasions, between 0.3 and 0.5 on 4 occasions, and greater than that only once. Plants from sites that were lightly or moderately infested had comparable PSU values. On 3 of the 16 sampling dates, lightly infested areas had significantly $(P<0.05)$ higher values than moderately infested areas. On 4 sampling dates this situation was reversed, and on 9 sampling dates there were no significant differences between light and moderate infestations. Plants from the heavily infested site tended to be more advanced phenologically than those from the other 2 sites. This was most readily seen by examining the relative rank of individual study areas with respect to PSU values (Table 2). The heavily

Table 2. Relative rank of individual study areas expressed as frequency of occurrence (\%) across all sampling dates.

\begin{tabular}{llccc}
\hline \hline & & \multicolumn{3}{c}{ Numeric rank of area } \\
\cline { 3 - 5 } Characteristic & Infestation & low & middle & high \\
\hline Phenology & light & 53 & 28 & 19 \\
& moderate & 47 & 22 & 31 \\
Plant moisture stress & heavy & 12 & 38 & 50 \\
& light & 88 & 6 & 6 \\
& moderate & 0 & 66 & 34 \\
& heavy & 13 & 28 & 59 \\
\hline
\end{tabular}

infested site had the highest value on $50 \%$ of the sample dates and the lowest value on only $12 \%$

Plant water potential values were more related to the degree of sagebrush infestation than was phenological development. Plants from the lightly infested site were consistently under less moisture stress than plants from the heavily infested site (Table 2). Mean differences between these 2 sites were less than 3 bars on 8 of the 16 sample dates, between 3 and 6 bars on 3 dates, and between 6 and 9 bars on the 5 remaining dates. Plants from the moderately infested area usually had intermediate water potential values. Similar results have been reported by Wambolt (1973) in conifer species and apparently reflect intraspecific competition for available moisture. Soil moisture content showed very consistent relationships among the 3 study areas. It was highest in the heavily infested site and lowest in the moderately infested area. It appeared, therefore, to have no easily identified cause-and-effect association with shrub density. In addition, soil moisture measurements seem to be in conflict with plant water potential observations. That is, high plant moisture stress was associated with higher soil moisture content. Similar results have been reported by Branson et al. (1976) during the spring period and by Haas and Dodd (1972) for mesquite in Texas. The most plausible explanation of this situation would appear to be site differences in osmotic potential of the soil and/or the plant. However, other factors such as vertical root distribution may also have contributed.

When phenological development was examined among all plants as a function of calendar date, it was apparent that a direct relationship existed which could be mathematically described as a simple linear expression:

$$
\hat{\mathbf{Y}}=\mathrm{a}+\mathrm{bX}
$$

where $\hat{Y}$ is the predicted numeric growth stage as described in Table 1 $X$ is the calendar date expressed as day of the year (92 to 301) $a$ and $b$ are regression coefficients

This relationship is illustrated by our data in Figure 2. The established relation between date and plant phenology is important

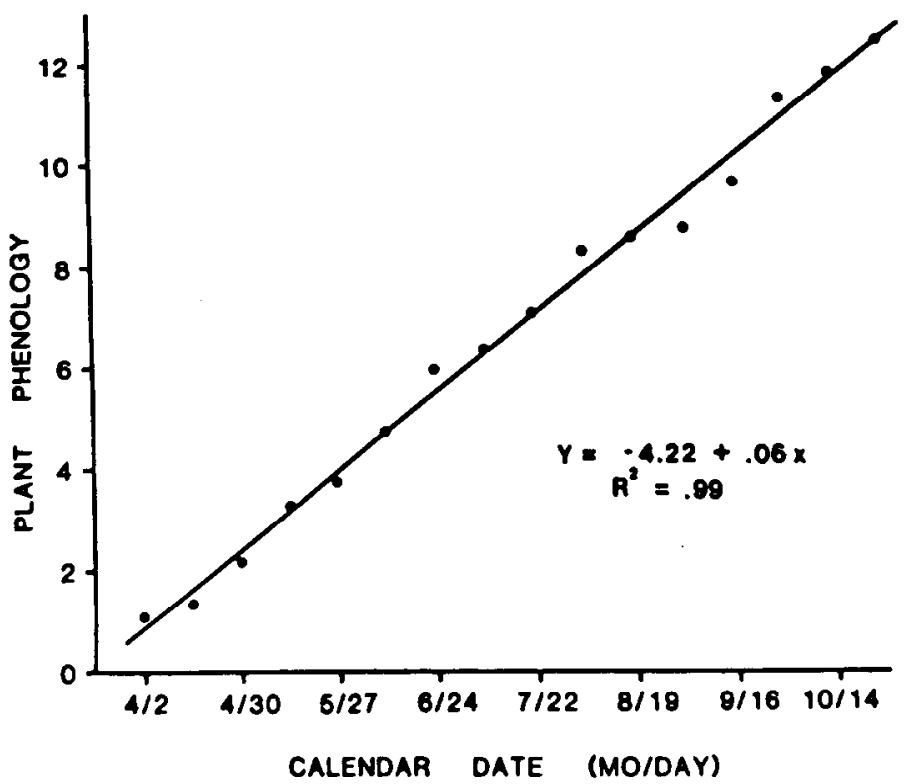

Fig. 2. Phenological development of silver sagebrush as observed from early April to late October. Each point represents a mean of 45 plants. Criteria used to establish numeric phenological scores are presented in Table 1.

because it demonstrates that changes in morphological attributes are readily described in silver sagebrush by a linear equation. The numeric values that were assigned to individual morphological stages of development were well suited to quantitative expression. Moreover, deviations from the regression line were small on individual sampling dates. As a result, the criteria that we established to describe plant phenology should have direct application in mathematical modeling in this or other similar species. In addition, discrete development stages are identified that can be examined in subsequent studies that address management of plant communities with silver sagebrush.

Evaluation of neutron probe data showed that seasonal shifts in

$$
\text { SOIL WATER CONTENT }(x)
$$

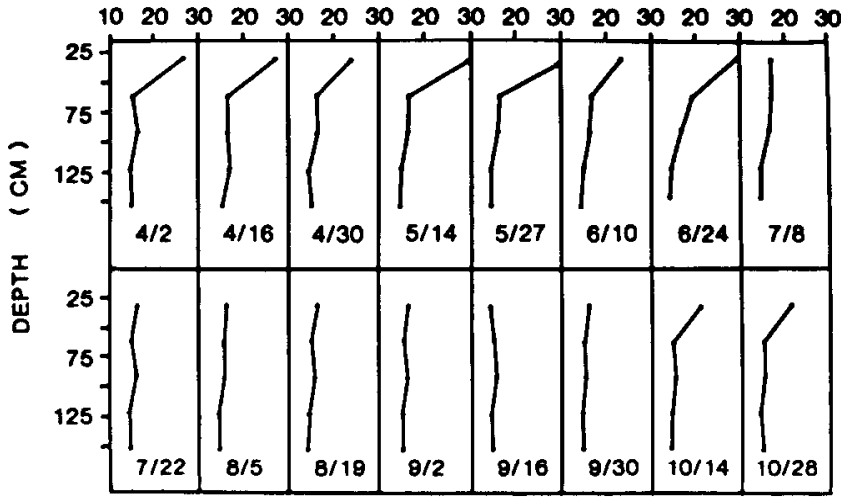

Fig. 3. Soil moisture profiles obtained by neutron attenuation from 12 access tubes at bi-weekly intervals from April to October. Individual sampling dates (mo/day) are indicated beneath each curve. 
moisture content were primarily restricted to the upper $60 \mathrm{~cm}$ of the soil profile (Fig. 3). Moisture content of this layer was relatively high until the end of June. As a result, silver sagebrush and other plant species were able to sustain vigorous growth during this period (Phenological stages 4.0 to 6.0 ). From early July until late September, soil moisture content was relatively low throughout the soil profile with little change from one sampling date to another. During this time period, silver sagebrush ceased stem elongation. Differentiation of reproductive parts, however, continued on a regular basis as flowers matured, were pollinated and developed seed (Phenological stages 7.0 to 11.0). Rainfall toward the end of summer and in early fall provided some recharge of the surface horizons, but soil moisture content did not attain as high a level as that observed during spring and early summer. During this interval, silver sagebrush seeds matured and seed dispersal began.

Changes in plant water potential primarily reflected changes in soil moisture content. These results were consistent with those reported for big sagebrush by Branson and Shown (1975). As the season advanced, there was an overall decrease in plant water potential (Fig. 4). During April and May, plant water potential was

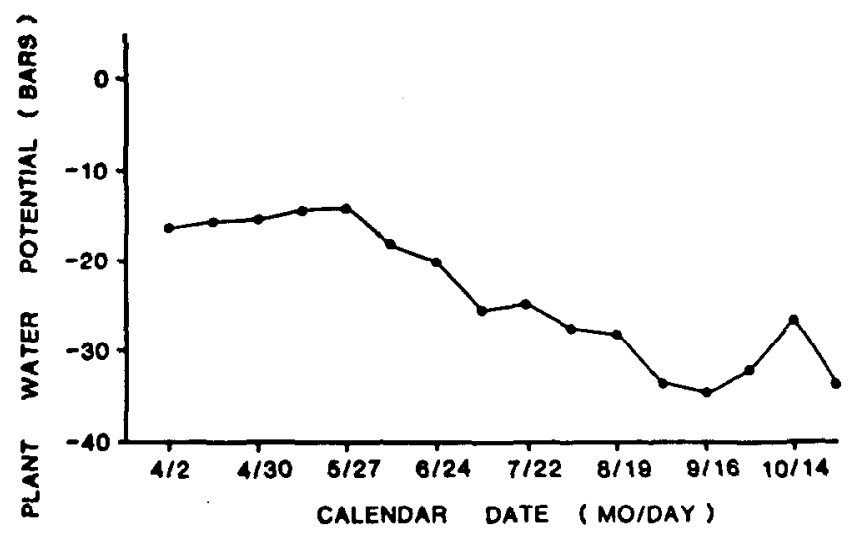

Fig. 4. Changes in plant water potential of silver sagebrush that were observed from early April to late October. Individual points on each date represent mean values from 45 plants.

approximately -15 bars. This corresponded to a time of the year when soil moisture content was favorable and air temperatures were relatively cool. In June, soil moisture continued to remain high, but plant water potential began to decrease. This decline appeared to be associated with increased air temperatures and vapor pressure deficits, and it can probably be attributed to proportionately higher rates of transpiration. Similar patterns have been reported in other shrub species (Moore et al. 1972), and Wambolt (1973) has pointed out the importance of these factors in influencing water potential. In July, August, and September, plant water potential continued to decline gradually to an average low of about -35 bars. This trend apparently resulted from continued depletion of soil water concomitant with lack of rainfall and maturation of reproductive parts in silver sagebrush. Improved soil moisture conditions and cooler temperatures in late September and early October were associated with a slight increase in plant water potential.

Examination of relationships between plant moisture stress and phenological development indicated that as stress became greater, plant phenology advanced (Fig. 5). It should be noted, however, that this response may be partially an artifact of statistical dependencies existing among date, plant water potential, and plant phenology. Since plant water potential decreased at the same time that calendar data advanced, these 2 factors are confounded to the extent that it is difficult to ascertain which is most critical to phenological development.

In summary, our work showed that distinct morphological

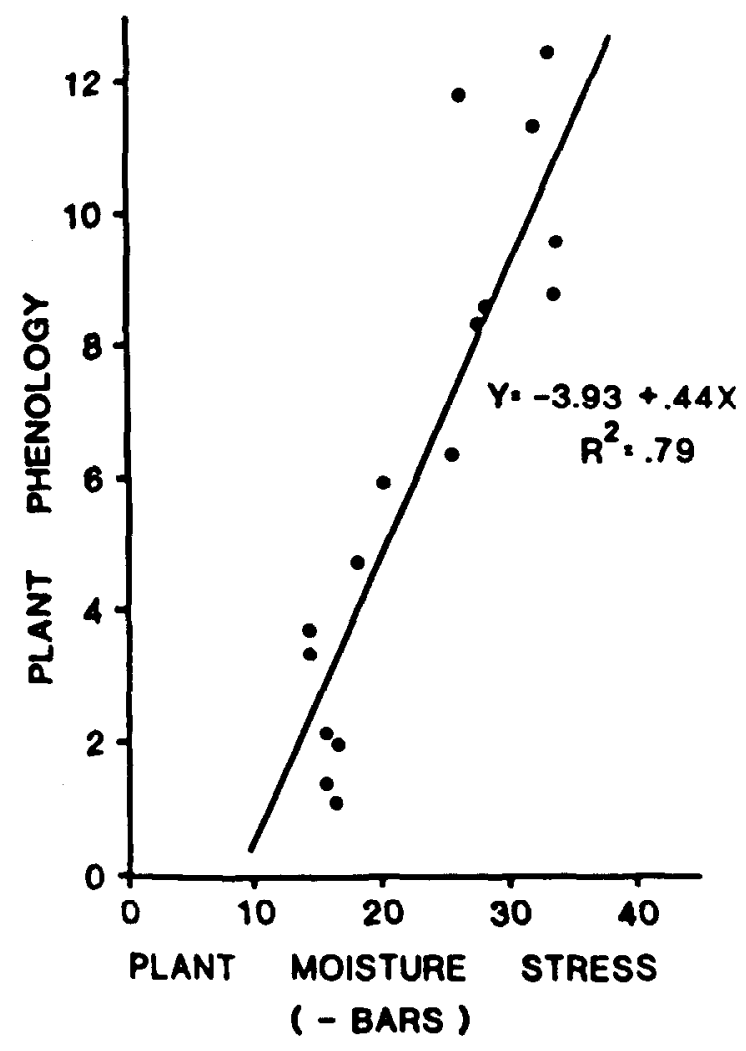

Fig. 5. Relationship between phenological development and plant moisture stress in silver sagebrush. Plant moisture stress data were obtained with a Scholander pressure bamb, and phenological scores were assigned according to criteria in Table 1.

stages exist in silver sagebrush that can be quantitatively characterized and described by linear regression. In doing this, a mathematical expression of phenological development was obtained that utilized either calendar date or plant water potential as independent variables. Water relations were determined for the species between early April and late October. This period corresponded to the interval that silver sagebrush was physiologically most active. Additional data will be needed to increase resolution of the phenological events that we observed in reference to year-to-year variation, but our work provides preliminary autecological information on the species. It should thereby furnish a better foundation for management of plant communities that contain silver sagebrush.

\section{Literature Cited}

Beetle, A.A. 1960. A study of sagebrush . Section Tridentatae of Artemisia. Wyom. Agr. Exp. Sta. Bull. 368.

Branson, F.A. and L.M. Shown. 1975. Soil-moisture stress as related to plant-moisture stress in big sagebrush. J. Range Manage. 28:212-215.

Branson, F.A., R.F. Miller, and I.S. McQueen. 1976. Moisture relationships in twelve northern desert shrub communities near Grand Junction, Colorado. Ecology 27:1 104-1124.

Campbell, G.S.,and G.A. Harris. 1977. Water relations and water use patterns for Artemisia tridentata Nutt. in wet and dry years. Ecology $58: 652-659$.

Daubenmire, R. 1978. Plant geography. Academic Press. New York.

DePuit, E.J., and M.M. Caldwell. 1973. Seasonal pattern of net photosynthesis of Artemisia tridentata. Amer. J. Bot. 60:426-435.

Has, R.H. and J.D. Dodd. 1972. Water-stress patterns in honey mesquite. Ecology. 53:674-680.

Harniss, R.O., S.J. Harvey, and R.B. Murray. 1981. A computerized bibliography of selected sagebrush species (genus Artemisia)in western North America. USDA Forest Serv., Gen. Tech. Rep. INT-102.

Harvey, S.J. 1981. Life history and reproductive strategies in Artemisia. M.S. Thesis, Montana State Univ., Bozeman. 
Hyder, D.N., F.A. Sneva, and V.H. Freed. 1962. Susceptibility of big sagebrush and green rabbitbrush to $2,4-\mathrm{D}$ as related to certain environmental, phenological and physiological conditions. Weeds 10:288-295.

Moore, R.T., R.S. White, and M.M. Caldwell. 1972. Transpiration of Atriplex confertifolia and Eurotia lanata in relation to soil, plant, and atmospheric moisture stresses. Can. J. Bot. 50:2411-2418.

Taylor, S.A. 1968. Terminology in plant and soil water relations. p. 49-72. In: T.T. Kozlowski (Ed.). Water deficits and plant growth. Academic Press, New York.
Wambolt, C.L. 1973. Conifer water potential as influenced by stand density and environmental factors. Can. J. Bot. 12:2333-2337.

Waring, R.H., and B.D. Cleary. 1967. Plant moisture stress: evaluation by pressurc bomb. Science 155:1248-1254.

Weaver, J.E., and F.E. Clements. 1938. Plant Ecology. McGraw-Hill Book Co., Inc., New York.

West, N.E., and R.W. Wein. 1971. A plant phenological index technique. BioScience 21:116-117.

White, R.S., and P.O. Currie. 1983. The effects of prescribed burning on silver sagebrush. J. Range Manage. 36:611-613. 